\title{
Инновационная технология полутвёрдого сыра из козьего молока для специализированного питания
}

\author{
Щетинина Елена Михайловна \\ ФГБОУ ВО «Алтайский государственный технический университет \\ им. И.И. Ползунова» \\ Адрес: 656038, г. Барнаул, пр. Ленина, д. 46 \\ E-mail: schetinina2014@bk.ru
}

\begin{abstract}
Гаврилова Наталья Борисовна ФГБОУВО «Омский государственный аграрный университет им. П. А. Столыпина» Адрес: 644008, г. Омск, Институтская площадь, д. 1 E-mail:nb.gavrilova@omgau.org
\end{abstract}

Чернопольская Наталья Леонидовна ФГБОУВО «Омский государственный аграрный университет им. П. А. Столыпина» Адрес: 644008, г. Омск, Институтская площадь, д. 1 E-mail:nl.chernopolskaya@omgau.org

Соловьева Наталья Ивановна КГБПОУ «Международный колледж сыроделия и профессиональных технологий» Адрес: 656038, г. Барнаул, ул. Путиловская, д. 51 E-mail: kollej.mks@mail.ru

\begin{abstract}
В статье представлено научное обоснование актуальности использования козьего молока для разработки технологии полутвёрдого сыра на его основе и расширения ассортимента производства сыров в России. Научная новизна исследований заключается в использовании молока коз зааненской породы Алтайского края в разработке технологии полутвердого сыра с повышенной биологической ценностью, а также экспериментально подтвержден способ повышения сыропригодности козьего молока путем внесения корректирующих ингредиентов: полисахарида и КНК. Использование комбинированных упаковочных материалов позволило увеличить срок годности сыра до трех месяцев во время хранения при температуре $4 \pm 2^{\circ} \mathrm{C}$. Приведены результаты экспериментальных исследований по выбору биотехнологических ингредиентов и разработке технологических параметров производства полутвёрдого козьегосыра, который рекомендуется для использования в процессе организации здорового питания населения разных возрастных групп, благодаря своей биологической ценности и функциональным свойствам.
\end{abstract}

Ключевые слова: Козье молоко, полутвёрдыйкозий сыр, специализированное питания

\section{Введение}

В России динамично растёт интерес населения всех возрастных групп к здоровому образу жизни, что неразрывно связано как с занятием профессиональным или любительским спортом, фит- несом, так и с организацией здорового питания. В документе «Основы государственной политики Российской Федерации в области здорового питания населения на период до 2020 года» поставлены задачи по развитию отрасли производства специализированной пищевой продукции ${ }^{1}$.

Распоряжение Правительства Российской Федерации от 25 октября 2010 г. № 1873-р. Основы государственной политики Российской Федерации в области здорового питания населения на период до 2020 года. URL: http://static.government.ru/media/ files/kMCUcrXb0YQseD91P8BQHdypkKROTyA3.pdf (дата обращения: 10.01.2021). 
К ним относятся в соответствии с ТР ТС 027/2012 2 такие виды специализированной пищевой продукции, как диетического лечебного питания, диетического профилактического питания, питания спортсменов, беременных и кормящих женщин, диабетического питания и др. Министерством здравоохранения РФ утверждены «Рекомендации по рациональным нормам потребления пищевых продуктов, отвечающих современным требованиям здорового питания» ${ }^{3}$, в которых наибольшая количественная доля приходится на молоко и молочные продукты.

Выполнение вышеизложенных задач возможно только при условии стабильного роста объёмов производства молока во всех видах хозяйств и при государственной поддержке молокопроизводителей.

Продовольственное эмбарго стало важнейшим фактором развития молочной отрасли России и прежде всего, производства сыра, которое начиная с 2014 г. и по настоящее время медленными темпами, но стабильно растёт (Рыбалова, 2017).

Обсуждая перспективные векторы, за счёт которых возможно дальнейшее развитие молочной отрасли и прежде всего, производства отечественных сыров, можно выделить следующие:

- фермерское движение в рамках его государственной поддержки;

- отечественное племенное животноводство и увеличение надоев;

- развитие козоводства и овцеводства;

- повышение качества и безопасности отечественных сыров при сопоставимом росте экономических возможностей их потребителей;

- техническое оснащение перерабатывающих предприятий преимущественно путём приобретения оборудования отечественных производителей (Русских, 2017).

Ю.Я. Свириденко отмечает, что производство сыра относится к наиболее ёмким по сырьевым ресурсам отрасли. В условиях дефицита натурального молока-сырья актуальна проблема организации рационального использования вторичных молочных ресурсов, как в натуральном, так и переработанном виде, что будет способствовать повышению эффективности производства сыра (Свириденко \& Волкова, 2013).

В молочной отрасли остаются неиспользованными значительные объёмы как творожный, так и подсырной сыворотки, которые необходимо применять в качестве функциональных ингредиентов, повышающих пищевую и биологическую ценность сыров и других молочных продуктов (Золоторев, Федотова, \& Агаркова, 2017).

К современным биоактивным сывороточным ингредиентам, представленным на мировом рынке, можно отнести: концентраты (КСБ), изоляты (ИСБ), гидролизаты (ГСБ) сывороточных белков; деминерализованную, делактозированную сыворотку; различные фракции белков; препараты лактоферрина, лактопе- роксидазы, пептидов; лактозу различной категории качества и ее производные (лактулоза, глюкозо-галакгозные сиропы, галактоолигосахариды, лактитол и др.). Производство таких ингредиентов успешно освоено за рубежом в основном в Европе, Северной Америке, Новой Зеландии, Японии. Лидерами являются такие компании, как AriaFoodIngredients, Euroserum, Ingredia, Glanbia, DairyCrest, Fonterra, Davisco, Westland, Morinaga и др. (Золоторева, Топалов, Евдокимов, \& Храмцов, 2017; Магомедов \& Рыбина, 2017; Affertsholt \& Pedersen, 2016).

Несмотря на существующие экономические трудности молочная отрасль постепенно развивается. Для удовлетворения потребностей населения в качественных молочных продуктах и прежде всего в натуральных отечественных сырах, в настоящее время часть молокоперерабатывающих предприятий решают вопросы с сырьём за счёт приобретения или создания собственных молочных комплексов. Поэтапное решение проблем технологической модернизации производителей молока, затрагивающих в том числе и интересы переработчиков (например, участие в приобретении оборудования для доения или охлаждения молока в счёт будущих поставок гарантированных объёмов молока-сырья высокого качества) - так же эффективный подход (Суровцев \& Никулина, 2018).

При этом, основной целью производства является комплексная переработка сырья в высококачественные и безопасные продукты при

2 ТР ТС 027/2012. О безопасности отдельных видов специализированной пищевой продукции, в том числе диетического лечебного и диетического профилактического питания. URL: http://docs.cntd.ru/document/902352823 (дата обращения: 21.01.2021).

3 Приказ Министерства здравоохранения РФ от 19 августа 2016 г. № 614. Об утверждении Рекомендаций по рациональным нормам потребления пищевых продуктов, отвечающих современным требованиям здорового питания. URL: https://www.garant. ru/products/ipo/prime/doc/71385784/ (дата обращения: 10.01.2021). 
минимально возможных затратах. Для этого необходимы современные технологии:

- глубокой переработки молочного сырья на основе концентрирования, фракционирования и направленной трансформации компонентов молока;

- по возможности максимального сохранения национальных продуктов и продолжать совершенствование их технологий;

- реализации современной системы контроля качества сырья и конечных продуктов;

- разрабатывать новые технологии, позволяющие как использовать нетрадиционное сырье, так и получать продукты, обладающие новыми потребительскими свойствами (Асафов \& Харитонов, 2018).

Важно подчеркнуть, что в современных условиях использование достижений науки и техники, биотехнологии, инновационные направления позволили создать новое поколение как традиционных, так и функциональных (обогащённых) и специализированных продуктов питания. Реализация современных технологических решений в их разработке невозможна без применения пищевых добавок, ароматизаторов, технологических вспомогательных средств, физиологически функциональных ингредиентов (Нечаев \& Краус, 2016).

Перспективным направлением является расширение производства функциональных и специализированных продуктов на молочной основе, обогащённых пробиотическими микроорганизмами в соответствии с ГОСТ 32923-2014 «Продукты кисломолочные, обогащённое пробиотическими микроорганизмами. Технические условия» (Ганина \& Ионова, 2018) в рамках исполнения рекомендаций по рациональным нормам потребления продуктов, которые отвечают современным требованиям здорового питания (Приказ Министерства здравоохранения РФ № 614 от 19.08.2016 г.) в соответствии с планом мероприятий по содействию импортозамещению в сельском хозяйстве (п. 16 «дорожной карты» Распоряжения Правительства РФ № 1948-р от 02.10.2014 г.) (Тихомирова, 2017). Сдерживающим фактором этого процесса является недостаточное количество молока коровьего сырого (ГОСТ 31449-20135), производимого в России.

Сыроделие - один из сегментов молочного рынка, который продолжает стабильно расти. В 2018 г. ли- дером по производству был Алтайский край, этому способствует политика импортозамещения. По данным выступления министра сельского хозяйства Республики Башкорстан, в республике разработана программа развития молочной отрасли до 2020 г. и в период до 2030 г. с намерением стать сырной столицей России. В настоящее время самым крупным в Башкирии сыродельным предприятием является Белебеевский молочный комбинат, производящий широкий ассортимент деликатесных сыров высокого качества (Гаврилова, Логинов, \& Линкевич, 2013; Линкевич \& Зарипов, 2013; Рыбалова, 2019).

Это стало возможным благодаря следующим факторам:

- оснащение предприятия самым современным оборудованием за счёт инвестиций компаний, владеющих контрольным пакетом акций;

- собственных ферм, на которых производится сыропригодное молоко;

- безотходное производство с переработкой подсырной, творожной сыворотки и пахты, образующихся в процессе выработки молочной продукции на предприятии.

В настоящее время в России все возрастные группы населения, включая молодое поколение, стремятся к «здоровому образу жизни» и больше заботится о своём питании, растёт спрос на продукты здорового питания.

В 2019 г. Роспотребнадзор в рамках национального проекта «Демография» начинает мероприятия, связанные с переходом на здоровое питание. В Правительстве РФ подготовлен проект закона об «идеологии здорового питания». В нем будут законодательно установлены понятия здорового питания и требования к нему. Для этого концептуально переработают Федеральный закон о качестве и безопасности пищевой продукции.

В сознании как зарубежных, так и российских потребителей молочные продукты с высоким содержанием белка, к которым относятся сыры, стойко ассоциируются с пользой для здоровья. Следует отметить, что в России с каждым годом все популярнее становится козоводство. Появились крупные промышленные и племенные фермы, активно развиваются средние и мелкие крестьянские (фермерские) хозяйства, растёт породное разнообразие коз (Темербаева, Гаврилова, \& Молибога, 2018).

\footnotetext{
4 ГОСТ 32923-2014. (2016). Продукты кисломолочные, обогащённое пробиотическими микроорганизмами. Технические условия. М.: Стандартинформ.

5 ГОСТ 31449-2013. Молоко коровье сырое. (2014). М.: Стандартинформ.
} 
Новым российским трендом является увлечение козьим молокоми продуктами его переработки (Рыбалова, 2019). Данный факт объясняется тем, что козье молоко обладает повышенной пищевой, биологической ценностью и гипоаллергенными свойствами. Его химический состав близок к женскому молоку. В связи с вышеизложенным козье молоко считается не заменимым сырьем для производства детских молочных продуктов, в том числе высокобелковых: творожных и сыра. Проведение исследований по разработке новых видов сыров с использованием козьего молока, обогащенных функциональными ингредиентами для специализированного - диетического, профилактического, спортивного, детского, гиродиетического питания является научно обоснованной.

Учитывая вышеизложенное необходимо отметить, что Правительство РФ за последнее время разработало ряд документов и проектов, призванных улучшить качество жизни населения, в том числе за счёт коррекции питания и организации производства продуктов здорового функционального и специализированного назначения:

доктрина продовольственной безопасности Российской Федерации утверждена 30 января 2010 г. Указом Президента РФ № 120 ;

основы государственной политики Российской Федерации в области здорового питания населения на период до 2020 года, утверждённые Распоряжением Правительства РФ от 25 октября 2010 г. № 1873-p;

стратегия повышения качества пищевой продукции в Российской Федерации до 2030 года, утверждённая распоряжение Правительства РФ от 29 июня 2016 г. № 1364-р (Раева, 2019);

федеральная научно-техническая программа развития сельского хозяйства на 2017-2025 годы утверждённая постановлением Правительства РФ от 25 августа 2017 г. № $996^{7}$.
Эффективная реализация этих программных документов, а также государственная программа РФ «Научно-технологическое развитие Россий-

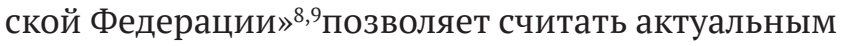
проведение исследований по созданию технологий сыров на основе козьего молока.

Цель исследования - разработка инновационной биотехнологии полутвёрдого сыра из козьего молока для специализированного питания.

\section{Материалы и методы исследования}

На различных этапах экспериментальных исследований, в качестве объектов использовались молочное сырьё, молочные смеси, промежуточные и готовые продукты, разнообразные ингредиенты, заквасочные культуры, в том числе:

- $\quad$ молоко козье сырое по ГОСТ 32940-20140;

- молоко натуральное коровье-сырьё по ГОСТ 52054-2003 ${ }^{11}$ (с изменениями № 1, 2);

- закваски бактериальные для производства молочной продукции по ГОСТ 34372-2017².

- ферментные препараты по действующей нормативной документации;

- фермент натурального происхождения от датского производителя: Chr. Hansen, NATURENExtra 220. Натуральный стандартизованный сычужный фермент животного происхождения с содержанием химозина и пепсина 95:5, изготовлен из натурального сычуга телят высшего сорта;

- химозинВалирен 150 Гранулар - микробиальный фермент неживотного происхождения, активность -150000 MCU/г;

- $\quad$ жидкий сычужный фермент Ceska-Lase (Kalase) натуральный телячий пепсин (реннет), производитель Нидерланды. Вырабатывается из желудков отборных телят, находившихся исключительно на диете из молока и молочных продуктов.используется для свёртывания молока в сыроделии;

\footnotetext{
6 Доктрина продовольственной безопасности Российской Федерации утверждена 30 января 2010 г. Указом Президента РФ № 120. URL: http://www.consultant.ru/document/cons_doc_LAW_96953/ (дата обращения: 14.01.2021).

7 Постановление Правительства Российской Федерации от 25 августа 2017 г. № 996 «Об утверждении Федеральной научно-технической программы развития сельского хозяйства на 2017-2025 годы». URL: https:/www.garant.ru/products/ipo/prime/ doc/71655402/ (дата обращения: 15.02.2021).

8 Постановление Правительства РФ от 29 марта 2019 г. № 377 - Об утверждении государственной программы Российской Федерации «Научно-технологическое развитие Российской Федерации». URL: https:/www.garant.ru/products/ipo/prime/ doc/72116664/ (дата обращения: 15.02.2021).

9 Рекомендации по развитию козоводства (2010). М.: ФГНУРосинформагротех».

${ }^{10}$ ГОСТ 32940-2014. (2014). Молоко козье сырое. М.: Стандартинформ.

${ }^{11}$ ГОСТ 52054-2003. (2003). Молоко коровье сырое. М.: Стандартинформ.

12 ГОСТ 34372-2017. (2017). Закваски бактериальные для производства молочной продукции. М.: Стандартинформ.
} 
- Ceska ${ }^{\circledR}$ CalciumCloride, хлористый кальций жидкий, используется при приготовлении сыра, для улучшения сычужной свёртываемости молока. Уменьшает время свёртываемости, увеличивает плотность сгустка. Позволяет получать более качественный сырный сгусток, производитель Нидерланды;

- полисахарид - цитрусовый пектин марки SLENDIDtype 200;

- концентрат натурального казеина (КНК) по действующей нормативной документации.

В процессе экспериментальной работы использовались физико-химические, биохимические, микробиологические,стандартные, общепринятые методы исследований. Определение пищевой и биологической ценности полутвёрдого сыра из козьего молокапроводилось в лаборатории ФГБУН «ФИЦ питания и биотехнологии» (г. Москва).

\section{Результаты и обсуждение}

Статистическая обработка результатов экспериментальных исследований проводилась с применением компьютерной программы «Statistica $6.14 »$.

В связи с тем, что в различных странах производится большое разнообразие сыров, выбрать их классификацию чрезвычайно сложно. Существует простейшая классификация сыров по их составу (Скотт, Рибинсон, \& Уилби, 2005), которая представлена в таблице 1.

Таблица 1

Простейшая классификация сыров по их составу

\begin{tabular}{lcc}
\hline тип сыра & $\begin{array}{c}\text { Содержание влаги } \\
\text { в обезжиренной } \\
\text { сырной массе,\% }\end{array}$ & $\begin{array}{c}\text { Содержание } \\
\text { жира в сухом } \\
\text { веществе, }\end{array}$ \\
\hline Очень твёрдый & $<51$ & $<60$ \\
Твёрдый & $49-55$ & $40-60$ \\
Полутвёрдый & $53-63$ & $25-50$ \\
Полумягкий & $61-68$ & $10-50$ \\
Мягкий & $>61$ & $10-50$ \\
\hline
\end{tabular}

Технология твёрдых и полутвёрдых сыров имеет видовые признаки, основным из которых является - температура второго нагревания, положенная в основу формирования двух групп сыров:

- с низкой температурой второго нагревания;

- c высокой температурой второго нагревания.
Так как производство сыра из козьего молока динамично развивается, то для промышленного производства необходимы научно обоснованные и практически апробированные технологии, сопровождаемые технической или нормативной документацией.

В качестве молочной основы для производства сыра изучено молоко зааненских коз Алтайского края. Среднестатистические данные физико-химических показателей козьего молока представлены в Таблице 2.

Таблице 2

Физико-химические показатели козьего молока

\begin{tabular}{lc}
\hline \multicolumn{1}{c}{ Наименование показателя } & Значения \\
\hline Массовая доля жира,\% & $4,30 \pm 0,05$ \\
Массовая доля влаги,\% & $87,66 \pm 0,04$ \\
Массовая доля сухих веществ,\% & $12,34 \pm 0,11$ \\
Массовая доля общего белка,\% в том & $3,04 \pm 0,03$ \\
числе & \\
Содержание сывороточных белков,\% & $0,77 \pm 0,01$ \\
Содержание казеиновых белков,\% & $1,86 \pm 0,01$ \\
Содержание общего азота,\% & $0,461 \pm 0,01$ \\
Содержание небелкового азота,\% & $0,0490 \pm 0,002$ \\
Массовая доля истинного белка,\% & $2,63 \pm 0,02$ \\
Содержание мочевины, мг\% & $57,90 \pm 0,03$ \\
Массовая доля лактозы,\% & $4,35 \pm 0,05$ \\
Кислотность, ${ }^{\circ}$ Т & $19,30 \pm 0,04$ \\
Плотность, кг/м & $1027,00 \pm 0,50$ \\
\hline
\end{tabular}

Результаты определения физико-химических показателей козьего молока свидетельствуют о том, что выбранное сырье соответствует требованиям ГОСТ 32940-2014 «Молоко козье сырое. Технические условия» и ТР ТС «О безопасности молока и молочной продукции» (ТР ТС 033/2013).

При разработке биотехнологических параметров производства полутвёрдого сыра с низкой температурой второго нагревания для исследования была выбрана бактериальная закваска производителя Sacco (Италия) - LyofastMT 096 FET $10 \mathrm{UC}$, в состав этой закваски входят специально отобранные штаммы Streptococcus thermophilus, Lactococcus lactis subsp. lactis, Lactococcus lactis subsp. Lactococcus lactis biovar diacetylactis, Lactobacillus delbrueckii subsp. lactis, Lactobacillus helveticus $u$ Leuconostoc subsp. Биотехнологические параметры производства нового вида полутвёрдого сыра из 
козьего молока разрабатывались опытно-экспе- в производственных условиях. Результаты предриментальным путём с последующей апробацией ставлены в Таблице 3.

Таблица 3

Основные биотехнологические параметры производства полутвёрдого сыра

Параметр производства $\quad$ Единицы измерения

Входной контроль сырья и материалов

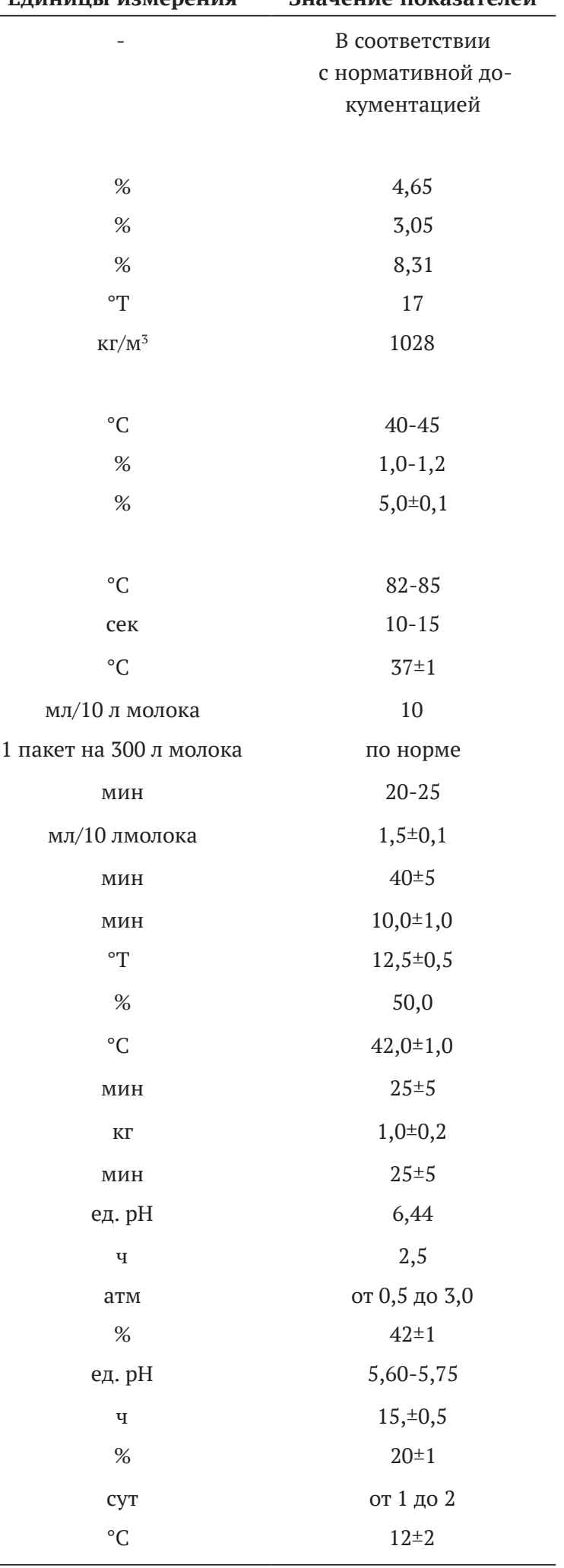

Основное сырьё - молоко коз зааненской породы:

- м.д.жира;

- м.д.белка;

- м.д.сухих веществ;

- кислотность;

- плотность

Подготовка молока к свёртыванию:

- подогрев до температуры

- внесение полисахарида

- внесение (КНК)

Пастеризация молока с корректирующими компонентами

выдержка

Охлаждение до температуры

Внесение жидкогоCaCl${ }_{2}$

Внесение закваски LyofastMT 096 FET 10 UC

Перемешивание

Свёртываниепутём внесения жидкого ФПКаalase

Время получения плотного сгустка

Вымешивание до кислотности сыворотки

Отлив сыворотки

Второе нагревание

Вымешивание

Формование в индивидуальных формах

Самопрессование

до рН сырной массы

Прессование, время

давление прессования

массовая доля влаги сырной массы

$\mathrm{pH}$

Посолка

в рассоле с концентрацией

Обсушка

при температуре

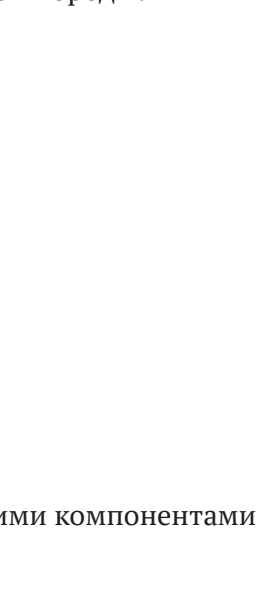


Таблица 3

\begin{tabular}{lcc}
\hline Упаковка & вид & термоусадочная \\
& & плёнка, латекс \\
Созревание & сут & 30 \\
при температуре & ${ }^{\circ} \mathrm{C}$ & $8-12$ \\
и влажности & $\%$ & $85-90$ \\
Хранение на предприятии не более & сут & 30 \\
Реализация & ${ }^{\circ} \mathrm{C}$ & $4 \pm 2$ \\
\hline
\end{tabular}

Технологический процесс выработки полутвёрдого козьего сыра, параметры производства которого представлены в Таблице 3, включает приёмку сырья в соответствии с действующей нормативно-технической документацией, резервирование молока при температуре $8-12^{\circ} \mathrm{C}$ на 10-14 часов.

Готовое молоко после внесения корректирующих ингредиентов отправляется на пастеризацию при температуре $82-85^{\circ} \mathrm{C}$, с выдержкой 10-15 секунд, с последующим охлаждением до температуры свёртывания $36-38^{\circ} \mathrm{C}$. В охлаждённое молоко вносится жидкий $\mathrm{CaCl}_{2}$ из расчёта 10 мл на 10 л молочной смеси, жидкий фермент Kalase и закваска LyofastMT 096 FET 10 UC.

Свёртывание производится при температуре 36$38^{\circ} \mathrm{C}$ в течении 35-45 минут. Сгусток получается ровный, плотный, хорошо отделяется сыворотка. Производится разрезка на кубики размером $1 \times 1 \mathrm{~cm}$ и постановка сырного зерна диаметром 6-8 мм в течение 15-19 минут.

Затем сырное зерно вымешивается в течение 9-11 минут и отливается 50\% сыворотки. На следующем этапе проводится второе нагревание при температуре $(41 \pm 1)^{\circ} \mathrm{C}$ в течение $15-20$ минут. Далее продолжается процесс вымешивания при температуре $(41 \pm 1)^{\circ} \mathrm{C}$ в течение 20-30 минут для обсушки зерна. Сыр формуется насыпью в пластиковые формы «Цилиндр 1 кг» и в течение 2030 минут проводится его самопрессование. Время прессования сыра в формах составляет 2,5 часа под давлением от 0,5 до 3,0 атм. Посолка сыра осуществляется в рассоле концентрацией 18-22\% при температуре $10-12^{\circ} \mathrm{C}$ в течении 15 часов. Обсушка сыра осуществляется при температуре $10-14^{\circ} \mathrm{C}$ в течении 1-2 суток. Созревает сыр 30 суток при температуре в камере от 8 до $12^{\circ} \mathrm{C}$ и относительной влажности воздуха от 85 до 90\%. Для изучения процесса созревания полутвёрдого сыра, его упаковывали в термоусадочную плёнку и латекс для сокращения трудоёмкости ухода за сыром в процессе созревания и повышения его качества.

Химический состав полутвёрдого козьего сыра в процессе хранения приведён в Таблице 4. Микробиологические показатели полутвердого козьего сыра представлены в Таблице 5.

Таблица 4

Химический состав полутвёрдого козьего сыра

\begin{tabular}{ccc}
\hline $\begin{array}{c}\text { Наименова- } \\
\text { ние показателя }\end{array}$ & $\begin{array}{c}\text { Возраст } \\
\text { 30 суток }\end{array}$ & Методика \\
\hline Массовая доля белка,\% & $26,0 \pm 1,5$ & ГОСТ Р 53951-2010 \\
Массовая доля влаги,\% & $43,0 \pm 1,0$ & ГОСТ 3626-73 \\
Массовая доля жира,\% & $26,1 \pm 1,0$ & ГОСТ 3626-73 \\
\hline
\end{tabular}

Таблица 5

Микробиологические показатели полутвердого козьего сыра

\begin{tabular}{lc}
\hline \multicolumn{1}{c}{ Наименование показателя } & $\begin{array}{c}\text { Значение } \\
\text { показателя }\end{array}$ \\
\hline $\begin{array}{l}\text { Мезофильный лактобактерии, } \\
\text { КОЕ/гр, не менее } \\
\text { Пробиотические микроорганизмы: }\end{array}$ & $6,4 \times 10^{9}$ \\
Lactobacillus bulgaricus; & \\
Lactobacillus helveticus, & $5,8 \times 10^{9}$ \\
КОЕ/гр, не менее & \\
\hline
\end{tabular}

Микробиологические показатели козьего полутвердого сыра свидетельствуют о том, что он является пищевым функциональным продуктом и соответствует ГОСТ Р 54060-2010 ${ }^{13}$.

Результаты изучения аминокислотного состава белков полутвёрдого козьего сыра, характеризующего его биологическую ценность представлены в Таблице 6.

\footnotetext{
${ }^{13}$ ГОСТ Р 54060-2010. Продукты пищевые функциональные. Идентификация. (2012). М.: Стандартинформ.
} 
Таблица 6

Аминокислотный состав белков козьего сыра в возрасте 30 суток

\begin{tabular}{|c|c|c|c|}
\hline Наименование & $\begin{array}{c}\text { Концентрация } \\
\text { мг/100 гр продукта }\end{array}$ & Погрешность & $\begin{array}{l}\text { Методика проведе- } \\
\text { ния исследований }\end{array}$ \\
\hline $\begin{array}{l}\text { Незаменимые аминокислоты, } \\
\text { в том числе: }\end{array}$ & 12760,0 & & \\
\hline Валин & 1500,0 & $10 \%$ & P4.1.1672-2003 \\
\hline Лейцин & 3600,0 & & \\
\hline Изолейцин & 1200,0 & & \\
\hline Лизин & 2700,0 & & \\
\hline Метионин & 580,0 & & \\
\hline Треонин & 1300,0 & & \\
\hline Фенилаланин & 1400,0 & & \\
\hline Трептофан & 480,0 & & \\
\hline Заменимые аминокислоты, в том числе: & 13100,0 & & \\
\hline Аспарагиновая кислота & 1600,0 & & \\
\hline Серин & 400,0 & & \\
\hline Глутаминовая кислота & 2160,0 & & \\
\hline Пролин & 1830,0 & & \\
\hline Глицин & 490,0 & & \\
\hline Аланин & 1800,0 & & \\
\hline Цистин & 1700,0 & & \\
\hline Тирозин & 1100,0 & & \\
\hline Гистидин & 1210,0 & & \\
\hline Аргинин & 810,0 & & \\
\hline Общее количество & 25860,0 & & \\
\hline
\end{tabular}

\section{Выводы}

В результате аналитических и экспериментальных исследований в статье дано научное обоснование актуальности разработки инновационной технологии полутвёрдого сыра на основе козьего молока, которая впервые использована на территории Алтайского края. Изучен химический состав и свойства молока коз зааненской породы Алтайского края. Экспериментально определены биотехнологические параметры производства нового вида полутвёрдого козьего сыра с низкой температурой второго нагревания, для производства которого разработана и утверждена нормативная документация СТО 38755528-004-2019 КГБПОУ «Международный колледж сыроделия и профессиональных технологий». Новый вид сыра отличается высокими органолептическими показателями, биологической ценностью и функциональными свойствами, так как закваска содержит пробиотические культуры. Использование комбинированных упаковочных материа- лов позволило увеличить срок годности сыра до трех месяцев во время хранения при температуpe $4 \pm 2{ }^{\circ} \mathrm{C}$. По результатам исследований подана заявка на патент.

\section{Благодарности}

Работа выполнена в рамках госзадания Минобрнауки РФ (государственное задание № 075-0031620-01 от 21.02.2020; мнемокод 0611-2020-013; номер темы FZMM-2020-0013).

\section{Литература}

Асафов, В. А, \& Харитонов, В. Д. (2018). Новые технологии и качество молочных продуктов. Молочная промышленность, 10, 39-41.

Гаврилова, Н. Б., Логинов, В. А., \& Линкевич, Е. Т. (2013). Технология полутвёрдого сыра «Премиум». Сыроделие и маслоделие, 1, 14-15. 
Ганина, В. И., \& Ионова, И. И. (2018). К вопросу о функциональных продуктах питания. Молочная промышленность, 3, 44-46.

Золотарев, Н. А., Федотова, О. Б., \& Агаркова, Е. Ю. (2017). Гидролизаты творожной сыворотки для творожных эмульсионных продуктов. Молочная промышленность, 8, 36-38.

Золоторева, М. С., Топалов, В. К., Евдокимов, И. А., \& Храмцов, А. Г. (2017). Молочная сыворотка - источник ценных пищевых ингредиентов и дополнительной прибыли. Сыроделие и маслоделие, 5, 30-31.

Линкевич, Е. Т., \& Зарипов, И. Р. (2013). Изучение технологических аспектов производства копчёных полутвёрдых сыров. Техника и технология пищевых производств, 1, 12-15.

Магомедов, Г. О., \& Рыбина А. В. (2017). Белковый снек с концентратом сывороточного белка для питания спортсменов. Сыроделие и маслоделие, 5, 32-33.

Нечаев, А. П., \& Краус, С. В. (2016). Развитие производства и рынка пищевых ингредиентов в России. В А. В. Гордеев (Ред.). Продовольственная независимость России (Ч. 2, с. 398-416). М.: ООО «Технология ЦД».

Раева, Н. Р. (2019). Качество и безопасность пищевой продукции изменения в санитарном законодательстве. Молочная промышленность, 9, 10-12.

Русских, В. М. (2017). Производство полутвёрдых сыров в крестьянско-фермерских хозяйствах. Молочная промышленность, 8, 48-49.
Рыбалова, Т. И. (2017). Современные векторы развития молочной отрасли России. Молочная промышленность, 8, 4-7.

Рыбалова, Т. И. (2019). Сыроделие и маслоделие: итоги 2018 г. Сыроделие и маслоделие, 1, 4-8.

Рыбалова, Т. И. (2019). Тренды и особенности потребительского поведения на молочном рынке. Сыроделие и маслоделие, 5, 25-28.

Свириденко, Ю. Я., \& Волкова, Т. А. (2013). Вторичное молочное сырье как эффективный ресурс для производства продуктов сыроделия и маслоделия. Сыроделие и маслоделие, 3, 34-38.

Скотт, Р., Робинсон, Р. К., \& Уилби, Р. А. (2005). Производства сыра: научные основы и технологии. СПб.: Профессия.

Суровцев, В. Н., \& Никулина, Ю. Н. (2018). Проблемы развития отрасли в условиях снижения потребления молочной продукции. Молочная промышленность, 10, 4-6.

Темербаева, М. В., Гаврилова, Н. Б., \& Молибога Е. А. (2018). Использование молока различных сельскохозяйственных животных для производства ферментированных продуктов. Молочная промышленность, 10, 46-48.

Тихомирова, Н. А. (2017). Формирование ассортимента и планирование объёмов производства отечественной молочной продукции. Молочная промышленность, 5, 24-25.

Affertsholt, T., \& Pedersen, D. (2016). The global market for whey and lactose ingredients 2016-2020. Whey Book. 


\title{
Innovative Semi-Hard Goat Cheese Technology for Specialized Nutrition
}

\author{
Elena M. Shchetinina \\ Polzunov Altai State Technical University \\ 46, Lenin Ave., Barnaul, 656038, Russian Federation \\ E-mail: schetinina2014@bk.ru
}

Natalia B. Gavrilova

Omsk State Agrarian University named after P. A. Stolypin 1, Institutskaya Square, Omsk, 644008, Russian Federation E-mail:nb.gavrilova@omgau.org

Natalia L. Chernopolskaya Omsk State Agrarian University named after P. A. Stolypin 1, Institutskaya Square, Omsk, 644008, Russian Federation E-mail: nl.chernopolskaya@omgau.org

\author{
Natalia I. Solovieva \\ International College of Cheese Making and Professional Technologies \\ 51, Putilovskaya st., Barnaul, 656038, Russian Federation \\ E-mail: kollej.mks@mail.ru
}

\begin{abstract}
The article presents a scientific substantiation of the relevance of the use of goat milk for the development of a technology for semi-hard cheese based on it and the expansion of the range of cheese production in Russia. The scientific novelty of the research lies in the use of milk from the Saanen breed of the Altai Territory in the development of a semi-hard cheese technology with an increased biological value, as well as an experimentally confirmed method of increasing the cheese suitability of goat milk by adding corrective ingredients: polysaccharide and KNK The use of combined packaging materials made it possible to increase the shelf life of the cheese up to three months during storage at a temperature of $4 \pm 2{ }^{\circ} \mathrm{C}$. The results of experimental studies on the selection of biotechnological ingredients and the development of technological parameters for the production of semi-hard goat cheese, which is recommended for use in the process of organizing healthy nutrition of the population of different age groups, due to its biological value and functional properties, are presented.
\end{abstract}

Keywords: Goat milk, semi-hard goat cheese, specialized food.

\section{References}

Asafov, V. A, \& Kharitonov, V. D. (2018). Novye tekhnologii i kachestvo molochnykh produktov [New technologies and quality of dairy products]. Molochnaya promyshlennost' [Dairy industry], 10, 39-41.

Gavrilova, N. B., Loginov, V. A., \& Linkevich, E. T. (2013). Tekhnologiya polutverdogo syra «Premium» [Technology of semi-hard cheese "Premium"]. Syrodelie $i$ maslodelie [Cheese making and butter making], 1, 14-15.

Ganina, V. I., \& Ionova, I. I. (2018). K voprosu o funktsional'nykh produktakh pitaniya [On functional food products]. Molochnaya promyshlennost' [Dairy industry], 3, 44-46.
Zolotarev, N. A., Fedotova, O. B., \& Agarkova, E. Yu. (2017). Gidrolizaty tvorozhnoi syvorotki dlya tvorozhnykh emul'sionnykh produktov [Hydrolysates of curd whey for curd emulsion products]. Molochnaya promyshlennost' [Dairy industry], 8, 36-38.

Zolotoreva, M. S., Topalov, V. K., Evdokimov, I. A., \& Khramtsov, A. G. (2017). Molochnaya syvorot$\mathrm{ka}$ - istochnik tsennykh pishchevykh ingredientov i dopolnitel'noi pribyli [Milk whey - a source of valuable food ingredients and additional profit]. Syrodelie i maslodelie [Cheese making and butter making], 5, 30-31.

Linkevich, E. T., \& Zaripov, I. R. (2013). Izuchenie tekhnologicheskikh aspektov proizvodstva kopchenykh polutverdykh syrov [Study of technological aspects of the production of smoked semi-hard 
cheeses]. Tekhnika i tekhnologiya pishchevykh proizvodstv [Technics and technology of food production], $1,12-15$.

Magomedov, G. O., \& Rybina A. V. (2017). Belkovyi snek s kontsentratom syvorotochnogo belka dlya pitaniya sportsmenov [Protein snack with whey protein concentrate for nutrition of athletes]. Syrodelie i maslodelie [Cheese making and butter making], 5, 32-33.

Nechaev, A. P., \& Kraus, S. V. (2016). Razvitie proizvodstva i rynka pishchevykh ingredientov v Rossii [Development of the production and market of food ingredients in Russia]. In A. V. Gordeev (Ed.). Prodovol'stvennaya nezavisimost' Rossii [Food independence of Russia] (Part. 2, pp. 398-416). Moscow: $\mathrm{OOO}$ «Tekhnologiya TsD».

Raeva, N. R. (2019). Kachestvo i bezopasnost' pishchevoi produktsii izmeneniya $\mathrm{V}$ sanitarnom zakonodatel'stve [The quality and safety of food products changes in sanitary legislation]. Molochnaya promyshlennost' [Dairy industry], 9, 10-12.

Russkikh, V. M. (2017). Proizvodstvo polutverdykh syrov $\mathrm{V}$ krest'yansko-fermerskikh khozyaistvakh [Production of semi-hard cheeses in peasant farms]. Molochnaya promyshlennost' [Dairy industry], 8, 48-49.

Rybalova, T. I. (2017). Sovremennye vektory razvitiya molochnoi otrasli Rossii [Modern vectors of development of the dairy industry in Russia]. Molochnaya promyshlennost' [Dairy industry], 8, 4-7.

Rybalova, T. I. (2019). Syrodelie i maslodelie: itogi $2018 \mathrm{~g}$ [Cheese-making and butter-making: results of 2018]. Syrodelie i maslodelie [Cheese making and butter making], 1, 4-8.

Rybalova, T. I. (2019). Trendy i osobennosti potrebitel'skogo povedeniya na molochnom rynke
[Trends and features of consumer behavior in the dairy market]. Syrodelie i maslodelie [Cheese making and butter making], 5, 25-28.

Sviridenko, Yu. Ya., \& Volkova, T. A. (2013). Vtorichnoe molochnoe syr'e kak effektivnyi resurs dlya proizvodstva produktov syrodeliya i maslodeliya [Secondary milk raw materials as an effective resource for the production of cheese and butter products]. Syrodelie i maslodelie [Cheese making and butter making], 3, 34-38.

Skott, R., Robinson, R. K., \& Uilbi, R. A. (2005). Proizvodstva syra: nauchnye osnovy i tekhnologii [Production of cheese: scientific foundations and technologies]. S-Petersburg: Professiya.

Surovtsev, V. N., \& Nikulina, Yu. N. (2018). Problemy razvitiya otrasli $\mathrm{v}$ usloviyakh snizheniya potrebleniya molochnoi produktsii [Problems of the industry development in the context of reducing the consumption of dairy products]. Molochnaya promyshlennost' [Dairy industry], 10, 4-6.

Temerbaeva, M. V., Gavrilova, N. B., \& Moliboga E. A. (2018). Ispol'zovanie moloka razlichnykh sel'skokhozyaistvennykh zhivotnykh dlya proizvodstva fermentirovannykh produktov [Use of milk of various agricultural animals for the production of fermented products]. Molochnaya promyshlennost' [Dairy industry], 10, 46-48.

Tikhomirova, N. A. (2017). Formirovanie assortimenta i planirovanie ob"emov proizvodstva otechestvennoi molochnoi produktsii [Formation of assortment and planning of production volumes of domestic dairy products]. Molochnaya promyshlennost' [Dairy industry], 5, 24-25.

Affertsholt, T., \& Pedersen, D. (2016). The global market for whey and lactose ingredients 2016-2020. Whey Book. 